\title{
Effects of Red Imported Fire Ants (Solenopsis invicta) on the Species Structure of Ant Communities in South China
}

\author{
by \\ Yong-yue $\mathrm{Lu}^{1^{*}}$, Bi-qiu Wu, Yi-juan Xu \& Ling Zeng
}

\begin{abstract}
We evaluated the effects of invasive red imported fire ants (RIFAs), Solenopsis invicta Buren, on native ant communities at three habitats in South China. By using paired control and treatment plots, the change in diversity and community structure of native ants due to the invasion of red imported fire ants could be observed. Ant species richness was reduced by 46 and $33 \%$ at RIFA-infested lawn and pasture habitats, respectively; however, the ant species richness in the lichee orchard was not affected by red imported fire ants. Our results indicated that red imported fire ants became one of several dominant species or the only dominant species in all three habitats in South China.
\end{abstract}

Key words: Solenopsis invicta Buren, ant species, community structure

\section{INTRODUCTION}

The red imported fire ant (RIFA), Solenopsis invicta Buren, has been listed as one of the most serious invasive alien species in the world (Lowe et al. 2004). S. invicta was first introduced into North America, at the seaport of Mobile, Alabama, USA from South America (Buren 1972, Vinson \& Sorensen 1986). After the introduction, its territory increased continually due to natural mating flights and human transportation. S. invicta then invaded Australia, New Zealand, Mainland China and Taiwan in 2001-2004 (Henshaw et al. 2005, Hoffmann \& O'Connor 2004, Zeng et al. 2005a, Zeng et al. 2005b, He et al. 2006).

The first $S$. invicta specimen was collected from Wuchuan, Guangdong on September 23, 2004, and was identified on September 28, 2004 in Mainland China (Zeng et al. 2005a). Later, S. invicta was found in three other prov-

\footnotetext{
${ }^{1}$ Red Imported Fire Ant Research Center, South China Agricultural University, Guangzhou 510642, P. R. China

*Corresponding author. Email: insectlu@163.com
} 
inces and two special administration districts, i.e. Guangxi, Hunan, Fujian, Hongkong and Macau (Zeng et al. 2005a; Zeng et al. 2005b; Zhang et al. 2007). S. invicta is a successful invader due to several reasons, including a wide range of climate tolerance, an ability to use a broad range of food resources, high fecundity and reproduction, and rapid colony establishment, especially in disturbed habitats (Vinson, 1997, Porter \& Savignano, 1990, Callcott \& Collins, 1996, Gotelli \& Arnett, 2000, Korzukhin et al. 2001, Porter et al. 1992). In Texas, the invasion of $S$. invicta in the late 1980's decimated the indigenous ant fauna, and the species richness of ants in RIFA-infested areas dropped by $70 \%$, while the total number of native individuals dropped by $90 \%$ (Porter \& Savignano 1990). Competitive replacement between $S$. invicta and local ants in the same or similar niches happened slowly (Porter et al. 1988, Vinson 1990). Several studies have also reported that the overall diversity and richness of native ant communities declined after the invasion of fire ants (Porter \& Savignano 1990, Wojcik 1994, Cook 2003).

S. invicta has infested urban, suburban and disturbed habitats in Mainland China (Zenget al. 2005, Li et al. 2005). A prediction of potential distribution area of $S$. invicta in China showed that these ants could occupy wide areas in the southeastern part of China with a northern boundary of Shandong and Tianjin as well as the southern parts of Hebei and Shanxi provinces (Xue et al. 2005, Morrison et al. 2004).

The objective of this study is to explore the effect of this pest invasion and infestation on pre-existingant communities in Mainland China. This study was initiated in the summer of 2005 and completed in the autumn of 2007.

\section{MATERIALS AND METHODS}

\section{Study areas}

Three areas, a lichee orchard, a pasture and lawn areas, infested with red imported fire ants in Shenzhen of Guangdong province in south China were chosen for sampling. The lichee orchard was located around a lake at Longgang, Shenzhen. The total acreage of the lichee orchard was approximately 100 ha. The percentage of weeds covering the ground surface was $60 \sim 80 \%$. Two blocks in the lichee orchard were chosen as the experimental sites. The infested block was $1.3 \mathrm{ha}$, and the density of active fire ant mounds was 18/ ha. The density of the uninfested (control) block was $1.2 /$ ha. The pasture 
and lawn areas were also in Longgang, Shenzhen. The percentage of the grass and weeds covering the ground surface was $80 \sim 95 \%$ at the pasture and lawn areas. The infested pasture area was $1.1 \mathrm{ha}$, and the control area was 1.3 ha. The density of active fire ant mounds reached $93 /$ ha in the pasture area, but the average was approximately $34 /$ ha. The infested lawn area was about $1.5 /$ ha with an active fire ant mound density of $95 /$ ha, and the control area was $0.8 / \mathrm{ha}$. Few weeds were found in the lawn area with the grass coverage of $100 \%$.

\section{Survey of ant community abundance and diversity}

Ground-dwelling ant species in both treatment and control sites were sampled using pitfall traps, bait vials, and visual searching according to previous description (Heyer et al. 1994). The combination of these methods is ideal for biodiversity monitoring programs and the comparison of ant communities among different habitats (Greenslade 1973, Heyer et al. 1994).

The collection was done twice a month from January to December. In each plot, 20 pitfall traps were divided into 5 groups. The interval distance between groups was $10 \mathrm{~m}$, and total area of 4 pitfall traps in each group was $1 \mathrm{~m}^{2}$. Traps were $100 \mathrm{ml}$ plastic vials $(15 \mathrm{~cm}$ in length, and $3 \mathrm{~cm}$ in diameter) filled with $45 \%$ ethyl alcohol at $1 / 3$ volume as a preservative. Each trap was inserted into the ground and the upper rim of the vial was same level as the soil surface. After $24 \mathrm{~h}$, each trap was removed from the soil, capped, and brought to the laboratory.

Bait vials were $50 \mathrm{ml}$ plastic vials $(7 \mathrm{~cm}$ in length, and $3 \mathrm{~cm}$ in diameter $)$ containing a $5 \times 25 \mathrm{~mm}$ circular hotdog slice (Shuanghui ${ }^{\text {txu }}$, GuangdongShuanghui Co., Guangodng) with several drops of honey (Baosheng ${ }^{\mathrm{TM}}$, Baoshengyuan Co., Shanghai). In total, 30 bait vials were placed at a distance interval of 10 $\mathrm{m}$ in each plot. Vials were set up at 08:00-10:00 during the warmer months and 12:00-14:00 during the colder months. Vials remained exposed for 30 min after they were covered, sealed, and then transported to the laboratory. Ants were collected and kept in $75 \%$ ethyl alcohol for identification and counting. If the bait was dominated by an individual ant species before the end of $30 \mathrm{~min}$ time period, it was covered and sealed to collect ants as soon as possible. The bait vial experiments were completed twice a month from January to December. 
The third method for collecting ants was visual searching. Each sampling plot was visually observed for two man-hours by three graduate students with previous survey experience of red imported fire ants. Litter, bare ground, tree trunks, foliage, decaying wood, and other surfaces were searched. Representative ants were collected and preserved. This method was also conducted twice a month from January to December.

All ants collected by these methods were initially identified through the comparison with specimens housed in the South China Agricultural University. Identifications of ant species were confirmed by Weiqiu Zhang (Department of Entomology, South China Agricultural University, Guangdong), Shanyi Zhou (School of Biological Science, Guangxi Normal University, Guangxi) according to the books written by Tang et al. (1995), Wu et al. (1995), and Zhou (2002). Voucher specimens have been deposited in the red imported fire ant research center, South China Agricultural University, Guangdong, China.

\section{Statistical analysis}

At each sampling site, diversity indices of ant communities in RIFA-infested and uninfested areas were calculated using identified ant species from above three methods. The Shannon-Weaver species diversity index $\left(H^{\prime}\right)$ was used to assess community structure (Keping Ma et al. 1994). The Shannon-Weaver diversity index $\left(H^{\prime}\right)$ was calculated by following equation: $H^{\prime}=-\Sigma \mathrm{p}_{\mathrm{i}} \times \ln \left(\mathrm{p}_{\mathrm{i}}\right)$, where $\mathrm{p}$ is the proportion of individuals in the $\mathrm{i}^{\text {th }}$ species relative to total species (Keping Ma et al. 1994). The diversity index $H^{\prime}$ 'was compared between the infested and uninfested areas through $t$-test (Keping Ma et al. 1994).

\section{RESULTS}

\section{Ant species}

Table 1 shows all species collected at each site through visual searching, pitfall traps and baits. The collected samples had 24 ant species belonging to 18 genera, 5 subfamilies, which included 5 genera and 5 species of Ponerinae, 1 genus and 1 species of Dorylinae, 7 genera and 10 species of Myrmicinae, 2 genera and 2 species of Dolichoderinae, and 3 genera and 5 species of Formicinae. 
Table 1. Ant species present in both infected and control plots at three habitats.

\begin{tabular}{|c|c|c|c|c|c|c|c|}
\hline \multirow[b]{2}{*}{ Subfamily } & \multirow[b]{2}{*}{ Species } & \multicolumn{2}{|c|}{ Lichee orchard } & \multicolumn{2}{|l|}{ Pasture } & \multicolumn{2}{|l|}{ Lawn } \\
\hline & & $\begin{array}{l}S . \text { invicta } \\
\text { present }\end{array}$ & $\begin{array}{l}\text { S. invicta } \\
\text { absent }\end{array}$ & $\begin{array}{l}\text { S. invicta } \\
\text { present }\end{array}$ & $\begin{array}{l}\text { S. invicta } \\
\text { absent }\end{array}$ & $\begin{array}{l}\text { S. invicta } \\
\text { present }\end{array}$ & $\begin{array}{l}\text { S. invicta } \\
\text { absent }\end{array}$ \\
\hline \multirow[t]{5}{*}{ Ponerinae } & Diacamma rugosum & $\sqrt{ }$ & $\sqrt{ }$ & & & & \\
\hline & Odontoponera transversa & $\sqrt{ }$ & $\sqrt{ }$ & & $\sqrt{ }$ & & $\sqrt{ }$ \\
\hline & Leptogenys chinensis & $\sqrt{ }$ & $\sqrt{ }$ & & $\sqrt{ }$ & $\sqrt{ }$ & $\sqrt{ }$ \\
\hline & Hypoponera confinis & & & & $\sqrt{ }$ & $\sqrt{ }$ & \\
\hline & Pachycondyla luteipes & & & & $\sqrt{ }$ & & \\
\hline Dorylinae & Dorylus orientalis & & $\sqrt{ }$ & & & & \\
\hline \multirow[t]{11}{*}{ Myrmicinae } & Pheidole pieli & $\sqrt{ }$ & $\sqrt{ }$ & $\sqrt{ }$ & $\sqrt{ }$ & & $\sqrt{ }$ \\
\hline & Pheidole yeensis & $\sqrt{ }$ & $\sqrt{ }$ & $\sqrt{ }$ & $\sqrt{ }$ & & $\sqrt{ }$ \\
\hline & Crematogaster biroi & & $\sqrt{ }$ & & & & \\
\hline & Tetramorium smithi & & $\sqrt{ }$ & $\sqrt{ }$ & $\sqrt{ }$ & & $\sqrt{ }$ \\
\hline & Tetramorium bicarinatum & & & & & & $\sqrt{ }$ \\
\hline & Pheidologeton diversus & $\sqrt{ }$ & $\sqrt{ }$ & $\sqrt{ }$ & $\sqrt{ }$ & & $\sqrt{ }$ \\
\hline & Solenopsis invicta & $\sqrt{ }$ & & $\sqrt{ }$ & & $\sqrt{ }$ & \\
\hline & Monomorium concolor & & $\sqrt{ }$ & $\sqrt{ }$ & $\sqrt{ }$ & $\sqrt{ }$ & $\sqrt{ }$ \\
\hline & Monomorium orientale & $\sqrt{ }$ & $\sqrt{ }$ & & $\sqrt{ }$ & & $\sqrt{ }$ \\
\hline & Monomorium pharaonis & & & & $\sqrt{ }$ & & $\sqrt{ }$ \\
\hline & Meranoplus bicolor & & & & & & $\sqrt{ }$ \\
\hline \multirow[t]{2}{*}{ Dolichoderinae } & Tapinoma melanocephalum & $\sqrt{ }$ & $\sqrt{ }$ & $\sqrt{ }$ & $\sqrt{ }$ & & $\sqrt{ }$ \\
\hline & Iridomyrmex anceps & & & $\sqrt{ }$ & & & \\
\hline \multirow[t]{5}{*}{ Formicinae } & Plagiolepis rothneyi & $\sqrt{ }$ & $\sqrt{ }$ & & $\sqrt{ }$ & & \\
\hline & Paratrechina flavipes & $\sqrt{ }$ & & $\sqrt{ }$ & $\sqrt{ }$ & $\sqrt{ }$ & \\
\hline & Paratrechina longicornis & $\sqrt{ }$ & & $\sqrt{ }$ & $\sqrt{ }$ & $\sqrt{ }$ & $\sqrt{ }$ \\
\hline & Paratrechina bourbonica & $\sqrt{ }$ & & & & $\sqrt{ }$ & \\
\hline & Camponotus dolendus & & $\sqrt{ }$ & & & & \\
\hline
\end{tabular}

${ }^{*} \mathrm{~A} \sqrt{ }$ designates the species as present.

Only 7 ant species were observed in the lawn area infested by red imported fire ants when all sampling methods were combined, while 13 ant species were found in the uninfested area. In addition, 10 and 15 ant species were observed at the RIFA-infested and uninfested pasture area respectively. 13 ant species were recorded at the RIFA-infested lichee orchard sites, and 14 ant species were recorded at the uninfested sites. The reduction of ant species richness was up to 46, 33 and 7\% at RIFA-infested lawn, pasture, and lichee orchard sites respectively when compared with the uninfested area (Table 1).

Generally, compared to the uninfested sites, the reduction of ant abundance was mainly due to the disappearance of some ant species in the infested sites of 
Table 2. Dominant species of ants in lichee orchard, pasture and lawn areas.

\begin{tabular}{|c|c|c|c|c|}
\hline Habitat & & $\begin{array}{l}\text { Number of } \\
\text { Dominant species }\end{array}$ & Dominant species & $\begin{array}{l}\text { Percentage (\%) *of } \\
\text { dominant species }\end{array}$ \\
\hline \multirow{2}{*}{$\begin{array}{l}\text { Lichee } \\
\text { orchard }\end{array}$} & S. invicta present & 3 & $\begin{array}{l}\text { Tapinoma melanocephalum } \\
\text { Solenopsis invicta } \\
\text { Pheidole pieli }\end{array}$ & $\begin{array}{l}36.8 \mathrm{a} \\
26.3 \mathrm{~b} \\
20.1 \mathrm{bc}\end{array}$ \\
\hline & S. invicta absent & 3 & $\begin{array}{l}\text { Tapinoma melanocephalum } \\
\text { Pheidole pieli } \\
\text { Pheidole yeensis }\end{array}$ & $\begin{array}{l}66.7 \mathrm{a} \\
18.1 \mathrm{~b} \\
11.3 \mathrm{bc}\end{array}$ \\
\hline \multirow[b]{2}{*}{ Pasture } & S. invicta present & 2 & $\begin{array}{l}\text { Solenopsis invicta } \\
\text { Tapinoma melanocephalum }\end{array}$ & $\begin{array}{l}74.6 \mathrm{a} \\
21.3 \mathrm{~b}\end{array}$ \\
\hline & S. invicta absent & 3 & $\begin{array}{l}\text { Pheidologeton diversus } \\
\text { Pheidole pielii } \\
\text { Tapinoma melanocephalum }\end{array}$ & $\begin{array}{l}42.7 \mathrm{a} \\
16.8 \mathrm{~b} \\
15.4 \mathrm{~b}\end{array}$ \\
\hline \multirow[b]{2}{*}{ Lawn } & S. invicta present & 1 & Solenopsis invicta & 98.9 \\
\hline & S. invicta absent & 3 & $\begin{array}{l}\text { Tapinoma melanocephalum } \\
\text { Pheidologeton diversus } \\
\text { Pheidole pielii } \\
\text { Monomorium concolor }\end{array}$ & $\begin{array}{l}32.7 \mathrm{a} \\
26.5 \mathrm{ab} \\
20.1 \mathrm{~b} \\
11.4 \mathrm{c}\end{array}$ \\
\hline
\end{tabular}

Data of treatment and control in the same habitat followed by same letter represents no significance at 0.05 (Ducan's DMRT).

two habitats. For example, 7 ant species (O. transversa, L. chinensis, H. confinis, $P$. luteipes, $M$. orientale, $M$. pharaonis and $P$. rothneyi) were not present at the pasture sites with red imported fire ants. While at the infested sites, several ant species (P. flavipes, P. longicornis, and P. bourbonica) were also recorded at the corresponding uninfested sites.

\section{Dominant species in ant communities}

Dominant species of ants in three habitats with and without red imported fire ants are listed in Table 2. The compositions of ant community were obviously changed after the introduction of red imported fire ants in our test sites in southern China. The fire ants became one of the dominant species or the only dominant species. The dominant ant species in the lichee orchard without infestion of fire ants were T. melanocephalum, P. pieli, and P. yeensis (Table 2). However, in the RIFA-infested lichee orchard, T. melanocephalum, S. invicta and P.pieli were dominant (Table 2). Moreover, the most dramatic change in 
Table 3. Indices of ant communities in different habitats.

\begin{tabular}{lllll}
\hline \hline Habitat & & Species number $(S)$ & $\begin{array}{l}\text { Total number of } \\
\text { individuals }(N)\end{array}$ & $\begin{array}{l}\text { Species diversity } \\
\text { index }\left(H^{\prime}\right)\end{array}$ \\
\hline Lichee orchard & S. invicta present & 14 & 10145 & $1.61^{*}$ \\
& S. invicta absent & 14 & 6162 & 1.03 \\
Pasture & S. invicta present & 10 & 19466 & 0.70 \\
& S. invicta absent & 15 & 6935 & $1.78^{* *}$ \\
Lawn & S. invicta present & 7 & 22475 & 0.07 \\
& S. invicta absent & 13 & 5865 & $1.66^{*}$ \\
\hline
\end{tabular}

${ }^{*}$ and ${ }^{* *}$ represent data where treatment and control in the same habitat were significantly different at 0.05 and 0.01 , respectively.

ant community structure was observed at the lawn site. Before the invasion of red imported fire ants, 4 dominant ant species were T. melanocephalum, $P$. diversus, $P$. pieli and $M$. concolor. In contrast, once the red imported fire ants occurred at the lawn site, they changed into the only dominant ant species.

\section{Diversity of ant community}

Three parameters of ant communities in different habitats were calculated (Table 3). The results revealed an obvious difference in ant species richness among three habitats. Compared with the area without red imported fire ants, the total number of individuals in the infested sites exhibited a significant increase. In addition, species diversity indices revealed a decrease at the RIFA-infested pasture and lawn sites. For example, the total ants captured at the RIFA-infested lawn site were 22475, while only 5865 ants were captured at the uninfested lawn sites. Species diversity index $H^{\prime}$ dropped from 1.66 to 0.07 . However, the ant species diversity index $H^{\prime}$ in the lichee orchard without red imported fire ants exhibited an increase.

\section{DISCUSSION}

The invasion of red imported fire ants resulted in a decline in species richness and changed the community structure of native ants in two habitats of southern China. Moreover, red imported fire ants replaced previously 
dominant ant species and became one of the dominant species or the only dominant species.

However, several problems in this study still need to be mentioned. The first one is that the density of active red imported fire ant mounds is relatively low at all experimental sites, which can result in a great variability in the population density of $S$. invicta. For example, the density of active mounds varies from 20-2100 colonies/ha at some places in Wuhucan, and from 12-1600 colonies/ha at other places of Shenzhen (Zeng et al. 2005a). Previous studies have revealed an overall negative correlation between $S$. invicta density and overall ant species richness as well as abundance (Stein \& Thorvilson 1989, Camilo \& Phillips 1990, Gotelli \& Arnett 2000). In the present study, we have analyzed the impact of fire ants at a low population density on native ant communities in some habitats of southern China. Therefore, ecological changes such as invasion of high-density fire ants are likely to cause much more dramatic impacts at some locations.

The second problem is that there are many habitats in southern China. Three common habitats such as lichee orchard, pasture, and lawn were selected as representative experimental sites to study the community structure and diversity of ants, but it is possible that high false positive results could have occurred due to the selection of limited types of ant habitats.

Given the environmental factors, differing impacts of $S$. invicta on ant diversity in three types of habitats probably showed that invader eco-function or eco-effect was related to the types of ecosystems and habitats in south China. The small impact of fire ants on the native ant community in lichee orchards may be due to high-population trees. In contrast, an obvious change in ant community structure at the lawn and pasture areas are likely due to the open community that is easily invaded by alien ant species.

The ecological impacts of red imported fire ant invasion have been explored in the past decades in the US. The invasion of red imported fire ants has been proved to reduce the species richness and abundance of many native ants and other arthropods (Nichols \& Sites 1989, Camilo \& Phillips 1990, Porter \& Savignano 1990, Morris \& Steigman 1993, Jusino-Atresino \& Phillips 1994, Kaspari 2000, Gotelli \& Arnett 2000, Summerlin et al.1984, Vinson 1991, Stoker et al. 1995). However, a positive correlation between $S$. invicta density and the diversity of ants and arthropods in stable post-invasion habitats has 
also been established (Morrison \& Porter 2003). Although a possible reason is that good environmental factors are good for both ants and other species, the post-invasion correlation probably does not reflect the ecological impacts of the original invasion.

After red imported fire ants were discovered at two locations in Brisbane, Australia in February, 2001, ecological effects of S. invicta were further investigated (Nattrass \& Vanderwoude 2001), revealing much lower abundance in ant species and invertebrates at the RIFA-infested sites when compared with uninfested sites (Nattrass \& Vanderwoude 2001). These studies indicate that the invasion of $S$. invicta may have a substantial impact on species richness and diversity of ant communities in disturbed urban and rural areas of China. However, the overall impact of $S$. invicta on ecosystems and biodiversity in Mainland China can only be determined by longer term and larger scale investigations in a wider variety of habitats.

\section{ACKNOWLEDGMENTS}

Wewould like to thankZhendong Song and Jun Huang for sample collection and surveys as well as Weiqiu Zhang for the identification of ant specimens. We also thank Sanford Porter (USDA-ARS) for manuscript editing. This work is supported by the National Natural Science Foundation of China (Award\# 305712427) and the National Basic Research Program of China (Award\# 2009CB119206).

\section{REFERENCES}

Buren, W.F. 1972. Revisionary studies on the taxonomy of the imported fire ants. J. Georgia Entomol. Soc. 7: 1-27.

Callcott, A.M.A. \& H.L. Collins 1996. Invasion and range expansion of imported fire ants (Hymenoptera: Formicidae) in North America from 1918-1995. Florida Entomologist 79:240-251.

Camilo, G. R. \&S.A. Phillips Jr 1990. Evolution of ant communities in response to invasion by the Tre ant Solenopsis invicta, pp. 190-198. In R. K. Vander Meer, K. Jaffe and A. Cedeno [eds.], Applied myrmecology: a world perspective. Westview Press, Boulder, CO.

Cook, J.L. 2003. Conservation of biodiversity in an area impacted by the red imported fire ant, Solenopsis invicta (Hymenoptera: Formicidae). Biodiversity Conserv. 12: 187-195.

Diffie, S. \& M.H. Bass 1994. Densities of monogynous red imported fire ant (Hymenoptera: Formicidae) colonies in Georgia pastures. J. Entomol. Sci. 29: 367-369.

Gotelli, N. J. \& A.E. Arnett 2000. Biogeographic effects of red fire ant invasion. Ecology Lett. 3: 257-261. 
Greenslade, P.J.M. 1973. Sampling ants with pitfall traps: digging-in effects. Insect. Soc. 20: 343-353.

He,X.F., Y.Y.Lu, W.Q.Zhang \& L.Zeng2006. Threehaplotypes found in introduced populations of red imported fire ant invading China. Acta Entomologia Sinica 49(6):1046 -1049.

Henshaw, M.T., N. Kunzmann, C.Vanderwoude, M. Sanetra \& R.H. Crozier 2005. Population genetics and history of the introduced fire ant, Solenopsis invicta Buren (Hymenoptera: Formicidae), in Australia. Australian Journal of Entomology 44(1):37-44

Heyer, W.R., M.A.Donnelly, R.W.McDiarmid,L.C.Hayek \& M.S. Foster 1994. Inventory and Monitoring. Pp. 117.In Measuringand monitoringbiological diversity: standard methods for amphibians. M. S. Foster, editor. Smithsonian Institution Press. Washington. USA.

Hoffmann, B.D. \& S. O'Connor 2004. Eradication of two exotic ants from Kakadu National Park. Ecological Management \& Restoration, 5(2):98-105

Jusino-Atresino, R.\& S.A.J. Phillips 1994. Impact of red imported fire ants on the ant fauna ocentral Texas. Pp. 259-268. in Exotic Ants: Biology, Impact, and Control of Introduced Species. DF Williams, editor. Westview Press, Boulder, Colorado.

Kaspari, M. 2000. Do imported fire ants impact canopy arthropods? Evidence from simple arboreal pitfall traps. Southwest. Nat. 45: 118-122.

Korzukhin, M.D., S.D. Porter, L.C. Thompson \& S.Wiley 2001. Modeling temperaturedependent range limits for the fire ant Solenopsis invicta (Hymenoptera: Formicidae) in the United States. Environ. Entomol. 30: 645-655.

Li, N.D., Y.Y. Lu, L. Zeng, G.W. Liang \& Y.J. Xu 2006. Study on Types of Environment, Spatial Ditribution and Sampling of Red Imported Fire Ant Solenopsis invicta Buren Active Mounds in Wuchuan,Guangdong Province. Journal of Huazhong Agricultural University, 25(1): 31-35.

Lowe, S., M. Browne, S. Boudjelas \& M. De Poorter 2004. 100 of the world's worst invasive alien species: a selection from the global invasive species database. The Invasive Species Specialist Group (ISSG), pp. 12.

Ma, K.P.\&Y.Q.Qian 1994. The Theory and Method of Research of Biodiversity. 1994. Beijing: China Science and Technology Press.

Morris, J. R. \& K.L. Steigman 1993. Effects of polygyne fire ant invasion on native ants of a blackland prairie in Texas. Southwest. Nat. 38: 136-140.

Morrison, L.W. \& S.D. Porter 2003. Positive association between densities of the red imported fire ant, Solenopsis invicta (hymenoptera: formicidae), and generalized ant and arthropod diversity. environ. entomol. 32(3): 548-554

Morrison, L.W., S.D. Porter, E. Daniels \& M.D. Korzukhin 2004. Potential global range expansion of the invasive fire ant, Solenopsis invicta. Biol. Invasions 6: 183-191.

Morrison,L.W.2002.Long-term impacts of an arthropod-community invasion by the imported fire ant, Solenopsis invicta. Ecology 83:2337-2345.

Nattrass, R. \& C. Vanderwoude 2001. A preliminary investigation of the ecological effects of red imported fire ants (Solenopsis invicta) in Brisbane. Ecol. Manage. and Restoration 2:220-223. 
Porter, S.D. \& D.A. Savignano 1990.nvasion of polygyne fire ants decimates native ants and disrupts arthropod community. Ecology, (71): 2095-2106

Porter, S.D., B. Van Eimeren \& L.E. Gilbert 1988: Invasion of red imported fire ants (Hymenoptera: Formicidae): microgeography of competitive replacement. Annals of the Entomological Society of America 81: 913-918.

Stein, M.B. \& H.G. Thorvilson 1989. Ant species sympatric with the red imported fire ant in southeastern Texas. Southwest. Entomol. 14: 225-231.

Stoker, R.L., W.E. Grant \& S.B. Vinson. 1995. Solenopsis invicta (Hymenoptera: Formicidae) effect on invertebrate decomposers of carrion in central Texas. Environ. Entomol. 24: 817-822.

Summerlin, J.W., H.D. Petersen \& R L. Harris. 1984. Red imported fire ant (Hymenoptera: Formicidae): effects on the horn fly (Diptera: Muscidae) and coprophagous scarabs. Environ. Entomol. 13: 1405-1410.

Tang,J., C.Li \& E.Y.Huan.1995. Economic Insect Fauna of China: Hymenoptera: Fornicidae (1). Beijing: Science Press

Vinson, S.B. \& A.A.Sorensen 1986. Imported fire ants: life history and impact. Texas Department of Agriculture, Austin, TX. Pp. 28.

Vinson, S.B. 1994. Impact of the invasion of Solenopsisinvicta (Buren) on native food webs. Pp. 240-258 in D. Williams, editor. Exotic Ants: Biology, Impact, and Control of Introduced Species. Westview Press. Boulder, Colorado

Vinson, S.B. 1997. The invasion of the red imported fire ant (Hymenoptera: Formicidae): spread, biology, and impact. Amer. Entomol. 43(1): 23-39.

Vinson, S.B. 1991. Effect of the red imported Tre ant (Hymenoptera: Formicidae) on a small plant-decomposing arthropod community. Environ. Entomol. 20: 98-103.

Wojcik, D.P. 1994. Impact of the red imported fire ant on native ant species in Florida. Pp. 269-281.in D. Williams, editor. Exotic Ants: Biology, Impact, and Control of Introduced Species. Westview Press. Boulder, Colorado.

Wu, J. \& C.L. Wang 1995. The Ants of China. Beijing: China Forestry Press

Xue, D.Y., H.M. Li, H.X. Han \& R.Z. Zhang 2005. A prediction of potential distribution area of Solenopsis invicta in China. Chinese Bulletin of Entomology, 42(1):57-60.

Zeng, L., Y.Y. Lu \& Z.N. Chen 2005. Management and surveillance of red imported fire ant. Guangdong Science \& Technique Press, Guangzhou, China, 106pp.

Zeng, L., Y.Y.Lu, X.F.He, W.Q.Zhang \& G.W.Liang 2005. Identification of red imported fire ant Solenopsis invicta to invade mainland China and infestation in Wuchuan冈Guangdong. Chinese Bulletin of Entomology, 42: 144-148.

Zhang, R.Z., I.C. Li, N. Liu \& S.D. Porter 2007. An overview of the red imported fire ant (hymenoptera: formicidae) in mainland china. Florida Entomologist,90(4):723-731

Zhao, Z.M. \& Y.Q. Guo 1990. The Theory and Method of Community Ecology. Chongqing: Science, Technology and Literature Press

Zhou, S.Y. 2001. The Ants of Guangxi. Guilin: Guangxi Normal University Press 
